\title{
Muğla İli Memeli Faunasına Katkılar
}

\author{
Yasin İLEMIN* \\ Muğla Sitkı Koçman Üniversitesi, Çevre Koruma Teknolojileri Bölümü, Muğla \\ (ORCID: 0000-0002-8240-4484)
}

\begin{abstract}
Öz
$\mathrm{Bu}$ araştırma ile çalışma bölgesindeki memeli faunasının ve bu türler üzerindeki tehditlerin belirlenmesi hedeflenmiştir. Arazi çalışmaları 2018 ve 2019 yıllarında yıl boyunca gerçekleştirilmiştir. Çalışmalar sonucunda 37 farklı karasal ve iç su memeli türü tespit edilmiştir. Alaca sansar (Vormela peregusna) türü Muğla için ilk kayıttır. Muğla İli için karayollarında araç çarpması sonucu ölen türlerin kayıtları tutulmuş, Porsuk (Meles meles), Kaya sansarı (Martes foina) ve Karakulak (Caracal caracal) populasyonlarının ciddi tehdit altında olduğu görülmüştür. Bu sonuçlara göre Muğla İlinde özellikle Köyceğiz, Döğüşbelen Mevkii, bir ekosistem köprüsü için uygun bir nokta olarak öne çıkmaktadır.
\end{abstract}

Anahtar Kelimeler: Memeli faunası, Muğla, Vormela peregusna.

\section{Contributions to the Mammalian Fauna of Muğla Province}

\begin{abstract}
This study aimed to identify the mammalian fauna in the study area and the threats on these species. Field studies were carried out throughout the year in 2018 and 2019. As a result of the studies, 37 different terrestrial and inland water mammal species have been identified. Marbled polecat (Vormela peregusna) is the first record for Muğla. The records of the species that died as a result of vehicle accidents on the highways for Muğla Province were kept and it was observed that Eurasian badger (Meles meles), Beech marten (Martes foina), Caracal (Caracal caracal) populations were under serious threat. According to these results, especially Köyceğiz, Döğüşbelen Mevkii in Muğla Province stands out as a suitable point for an ecosystem bridge.
\end{abstract}

Keywords: Mammal fauna, Muğla, Vormela peregusna.

\section{Giriş}

Ülkemizinin Güneybatısında bulunan ve birçok el değmemiş habitat barındıran Muğla ili karasal ve iç su ekosistemlerindeki memeli türleri üzerinde yapılan araştırmalar çok kısıtlı olup, birkaç araştırmacının yaptığı çalışmalara dayanmaktadır. Bu çalışmada Muğla İli karasal ve iç su Memeli faunası ile ilgili güncel bir literatür araştırması yapılmış ardından arazi çalışmaları sonucunda elde edilen bulgular paylaşılmıştır. Böylece Muğla İli’nde yaşayan türlerin belirlenmesi ve bunlar üzerindeki tehditlerin güncel durumunun ortaya konulması amaçlanmıştır.

\section{Materyal ve Metot}

Sistematik arazi çalışmaları ve literatür taramaları Muğla İlindeki bütün karasal ve içsu ekosistemlerinin tamamını kapsayacak şekilde 2018 ve 2019 yılları boyunca gerçekleştirilmiştir (Şekil 1).

Büyük memelilerin gözlenmesi ve kaydedilmesinde dürbün, fotokapan, fotoğraf makinesi gibi çalışılan türlere uygun malzemeler kullanılmıştır. Araç çarpması sonucu ölmüş memeli türleri kayıt edilmiştir. Gözlem yapılan alanların ve tespit edilen türlerin koordinatları Küresel Konum Belirleme Aracı (GPS) yardımıyla kayıt edilmiştir. Arazi gözlemleri sırasında, memelilere ait ayak izi, dışkı, ses

"Sorumlu yazar: yasinilemin@mu.edu.tr

Geliş Tarihi: 12.02.2020, Kabul Tarihi: 18.03 .2020 
(yarasaların ultrasonik dedektör ile tespiti) ve emarelerden yararlanma esasına dayalı dolaylı gözlemler de yapılmıştır. Kemiriciler ve böcekçiller için canlı yakalama kapanları kullanılmıştır. Yarasa türlerine ait tespitler ultrasonik dedektör (Pettersson D 500x) ile yapılmışıtı. Ayrıca bölgedeki mağara, mazgal, eski binalar, kaleler gibi ortamlara girilerek tüneklerinde türler veya dışkıları fotoğraflanmıştır.

Memeli yaban hayvanlarının envanterinin çıkarılmasının yanı sıra, populasyon durumu ve populasyonların tehdit eden faktörler belirlenmiştir. Populasyon durumu değerlendirmeleri yapılırken 3 kategori oluşturulmuştur. Yıllar içinde yapılan gözlemlere göre ilgili türün kayıt frekanslarında azalma var ise durumu "azalan", kayıt frekansları değişmiyorsa "sabit" ve kayıt frekansları yıllar içinde artıyorsa "artan" şeklinde kategorilendirilmiştir.
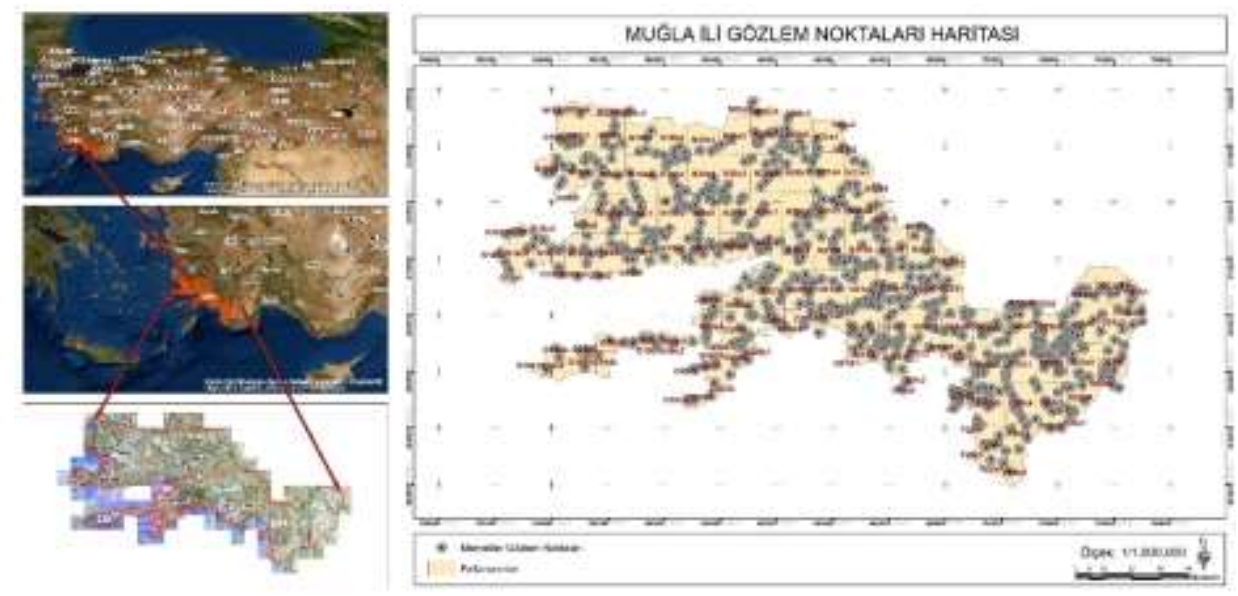

Şekil 1. Çalışma alanının konumu

\section{Bulgular ve Tartışma}

Bu proje kapsamında 37 karasal memeli türü tespit edilmiştir. Alaca sansar (Vormela peregusna), ilk defa bu proje kapsamında Muğla İlinde kayıt altına alınmıştır. Arazi çalışmaları kapsamında tespit şekillerine göre elde edilen bulgulardan bazıları aşağıda verilmektedir.

\section{Doğrudan Fotoğraflama}

Arazi çalışmaları sırasında memeli türlerinin çıplak gözle tespit edilebildiği durumlarda fotoğrafları çekilmiştir. Buna göre Marmaris-Aksaz'da yapılan saha çalışmaları esnasında yaban keçisi (Capra aegagrus) görülmüş ve fotoğraflanmıştır (Şekil 2). Milas İncirliin Mağarasında Büyük nalburunlu yarasa (Rhinolophus ferrumequinum) tespit edilmiştir (Şekil 3). Seydikemer İlçesi, Çaltı̈̈zü Mahhallesinde Vedat Karakaya tarafından bir kurt (Canis lupus) tespit edilmiştir (Şekil 4). Alaca Sansar (Vormela peregusna), Muğla için ilk kayıt olmuştur. Tepsit edilen bu Alaca sansar bireyi, Seydikemer İlçesi, Temel Mahallesi, Kıncılar mevkiinde (Girdev yaylası), ormanlık alanda dolaşan Şevket Taşçı tarafindan görülmüş, fotoğraflanmış ve tarafımıza bulgu olarak ulaştırılmıştır (Şekil 5). Görüldüğü mevkii, 1200-1500 m rakımlar arasında değişen bir yükseltiye sahiptir. 


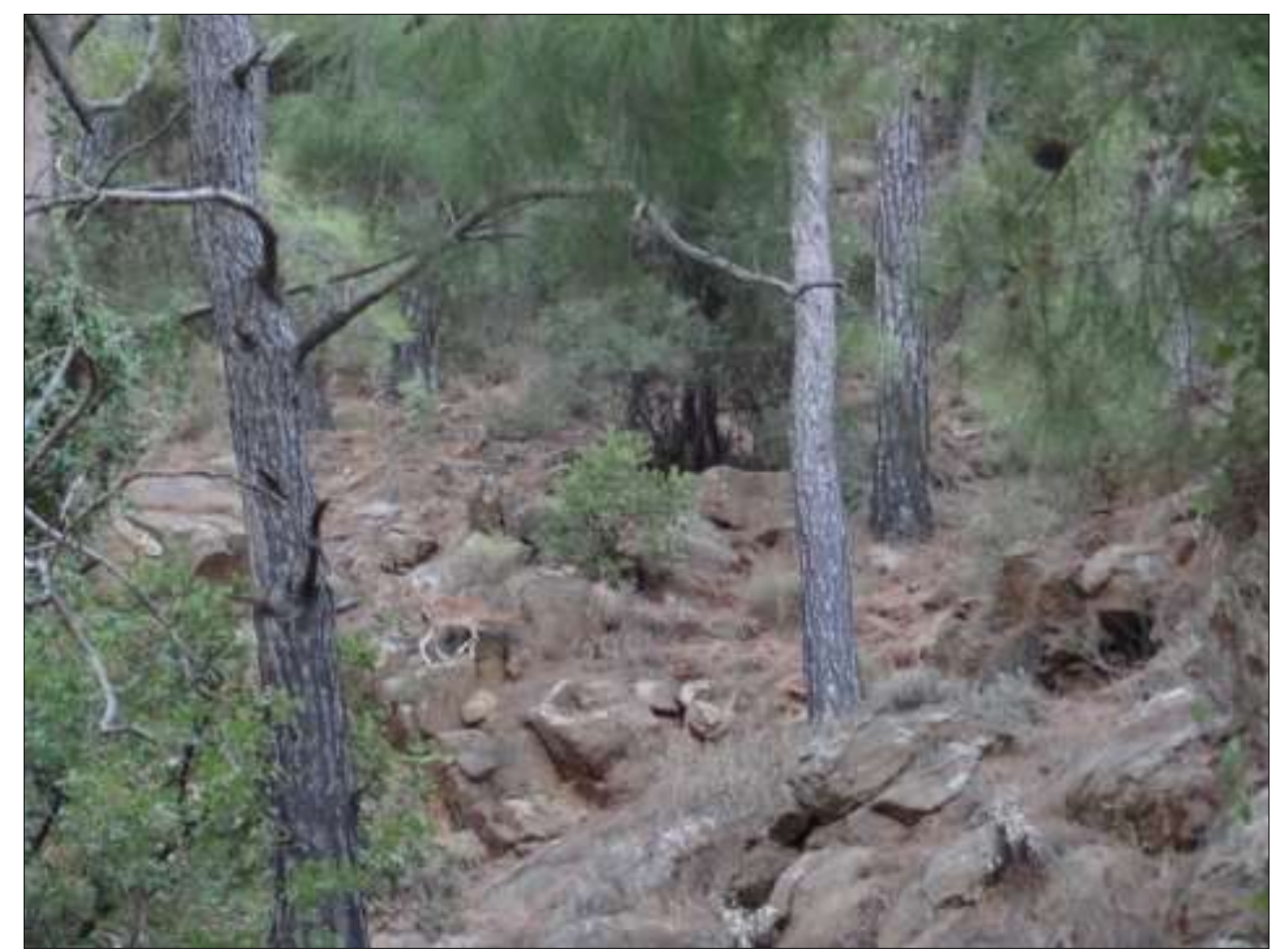

Şekil 2. Tespit edilen dişi yaban keçisi (Capra aegagrus)

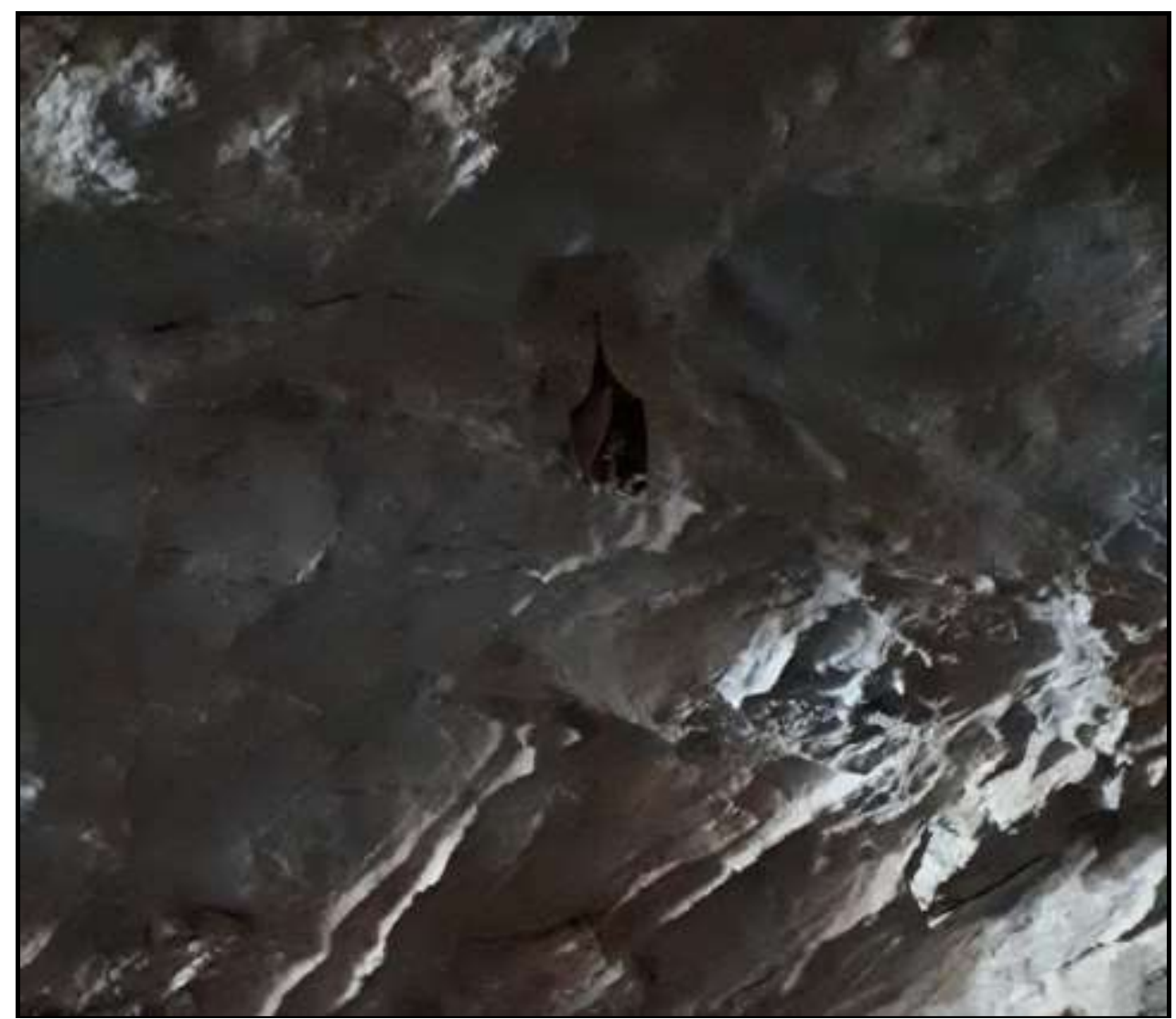

Şekil 3. Nalburunlu yarasa (Rhinolophus ferrumequinum) 


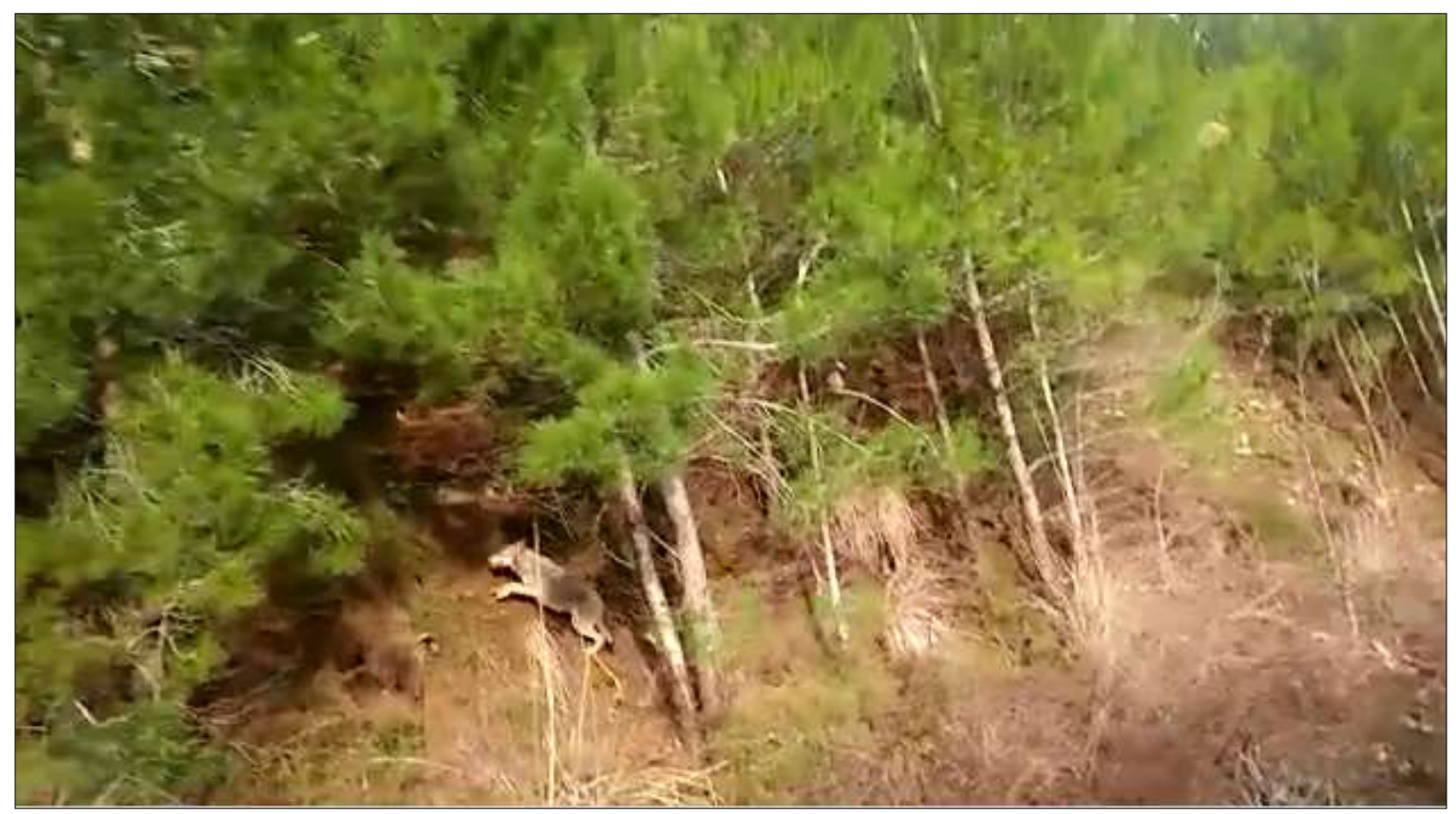

Şekil 4. Kurt (Canis lupus)

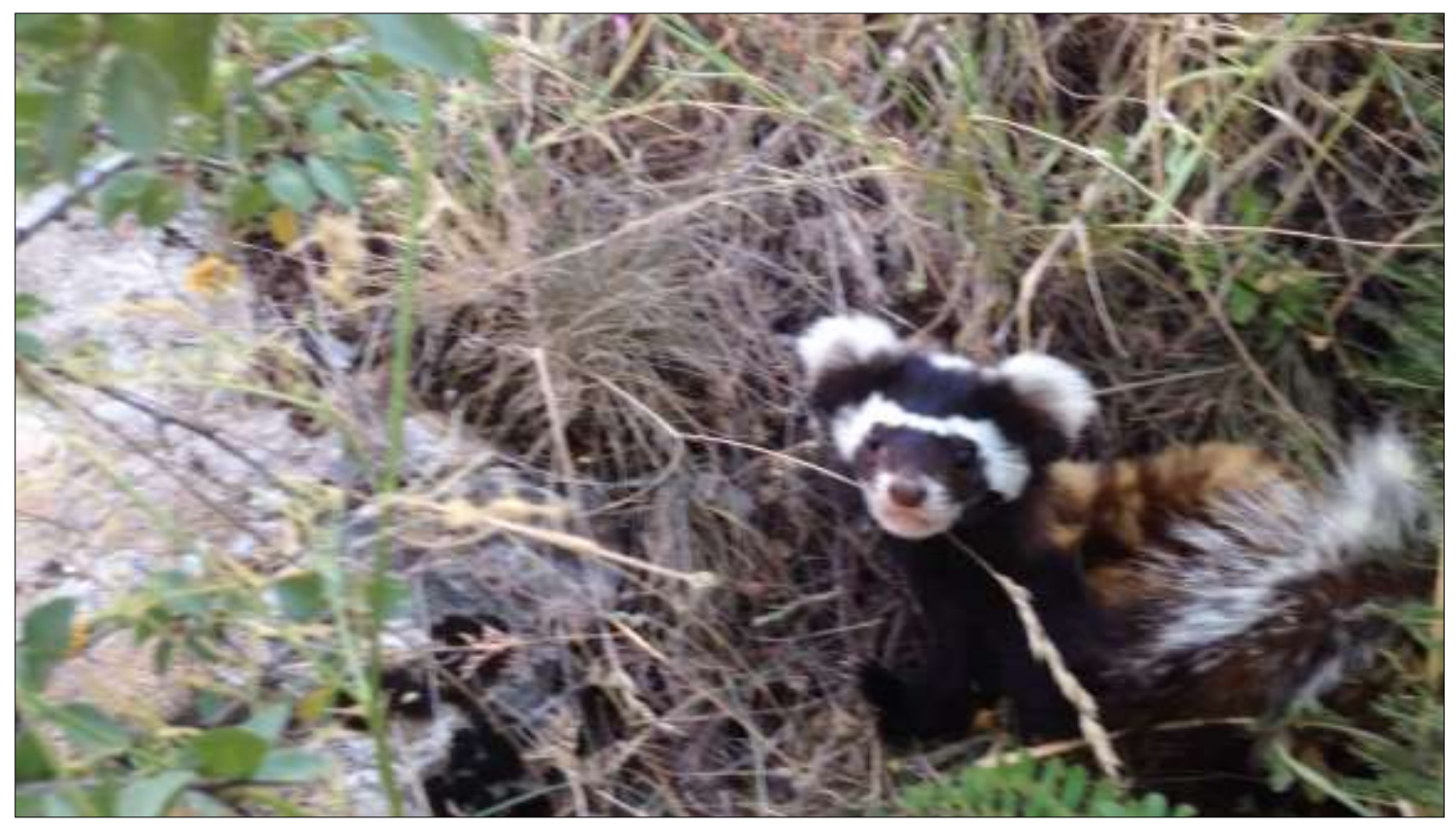

Şekil 5. Muğla için ilk kayıt olan Alaca sansar (Vormela peregusna)

\section{Ayak İzi ve diğer izler (beslenme belirtisi)}

Köyceğiz İlçesi Hamitköy Mahallesinde yapılan arazi çalışmalarında porsuk (Meles meles) türüne ait ayak izleri tespit edilmiştir (Şekil 6). Apodemus (Orman fareleri) cinsine ait beslenme belirtileri görülmüştür (Şekil 7). Yaban domuzlarının (Sus scrofa) toprağı burunları ile kazarak toprak altında buldukları besinleri (kök, yumru, mantar vs.) tükettiklerine dair emareler görülmüştür (Şekil 8). 


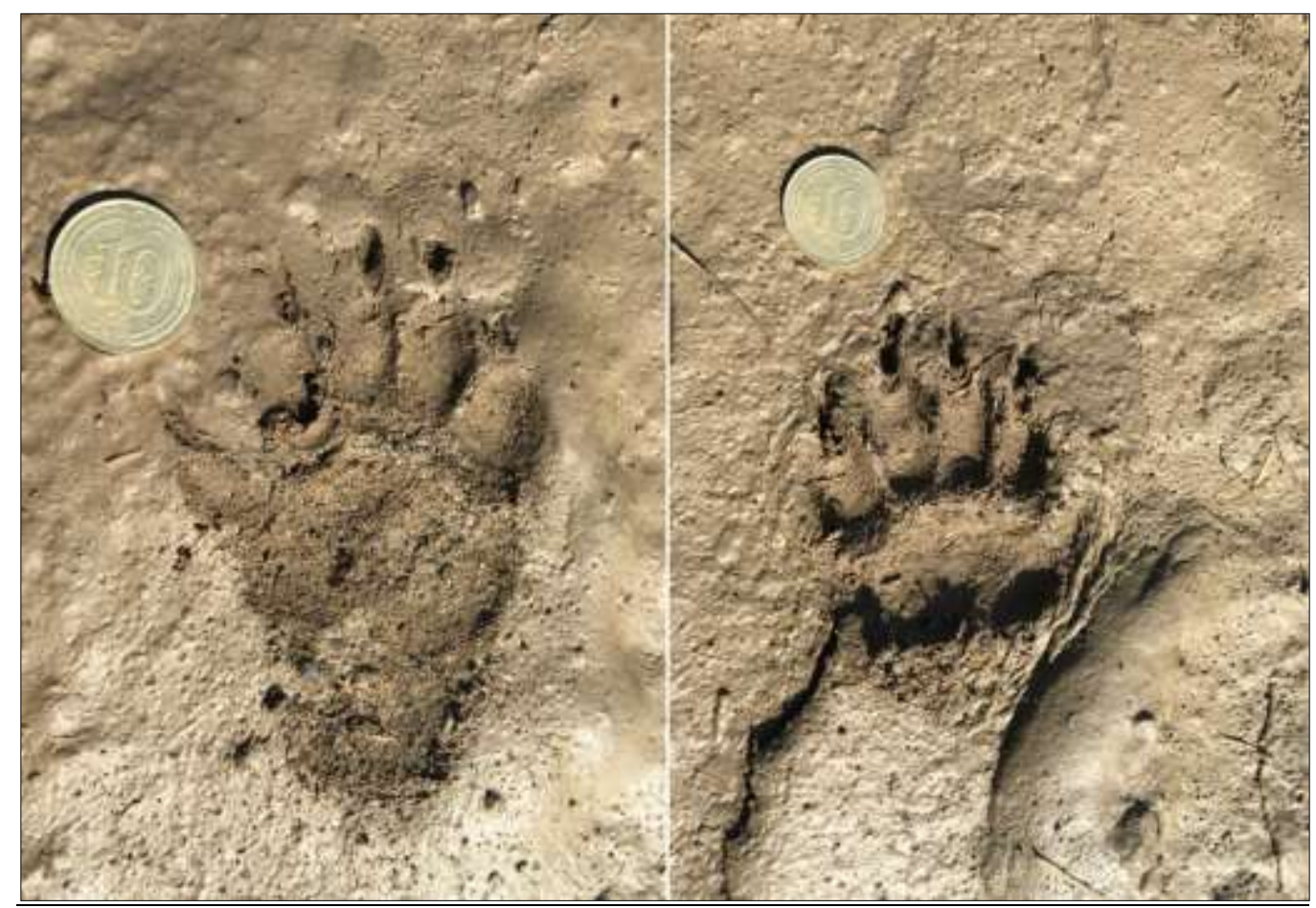

Şekil 6. Tespit edilen porsuk (Meles meles) türüne ait arka (soldaki) ve ön (sağdaki) ayak izleri

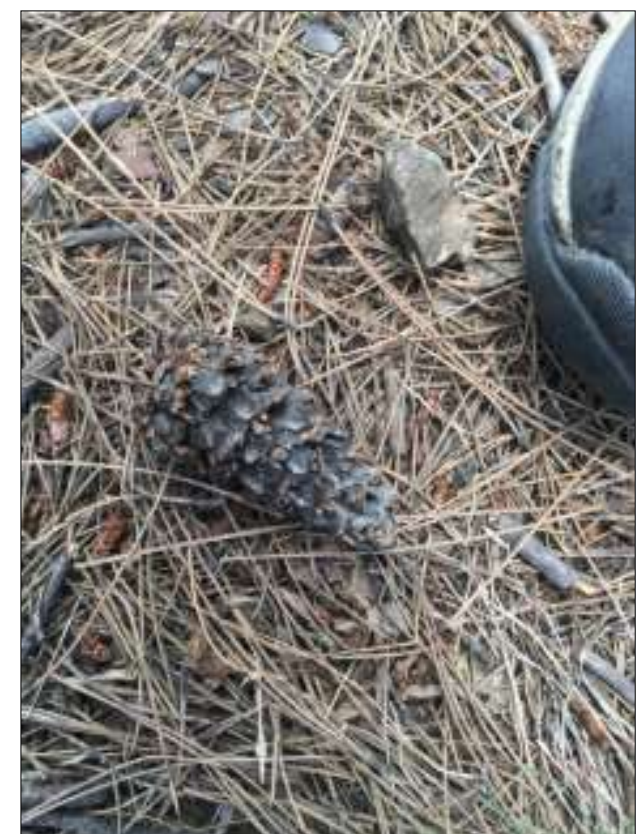

Şekil 7. Apodemus cinsine ait beslenme kalıntıları 


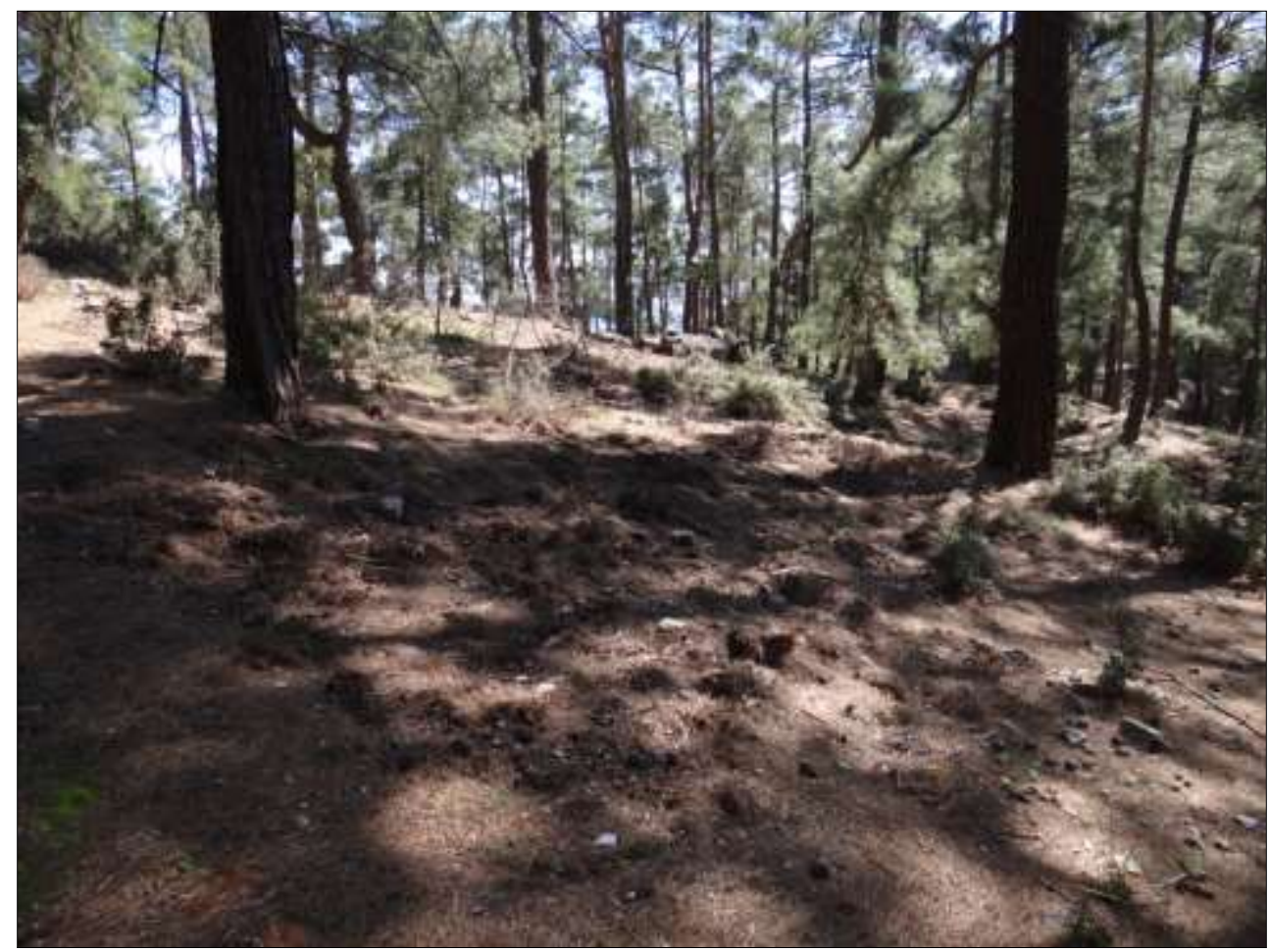

Şekil 8. Yaban domuzlarına ait beslenme izleri

\section{Dișki Ille Tespit}

Köyceğiz İlçesi Zeytinalanı Mahallesinde yapılan arazi çalışmaları esnasında Köyceğiz gölü kıyısında su samuru (Lutra lutra) türüne ait dışkı tespit edilmiştir (Şekil 9). Arazi çalışmaları sırasında tespit edilen farklı türlerin dışkılarına ait fotoğraflar Şekil 10' da verilmektedir.

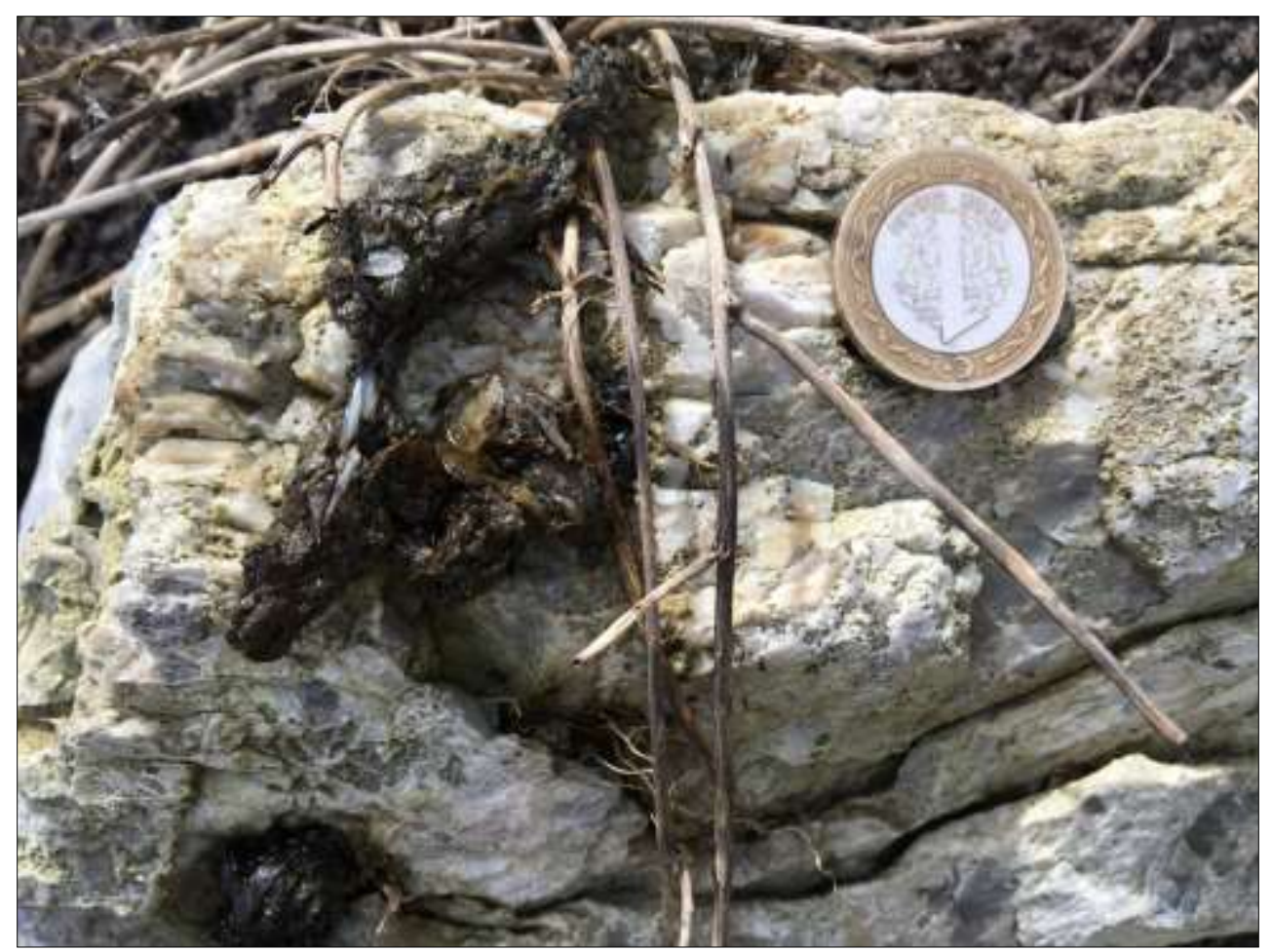

Şekil 9. Su samuru (Lutra lutra) dışkısı 


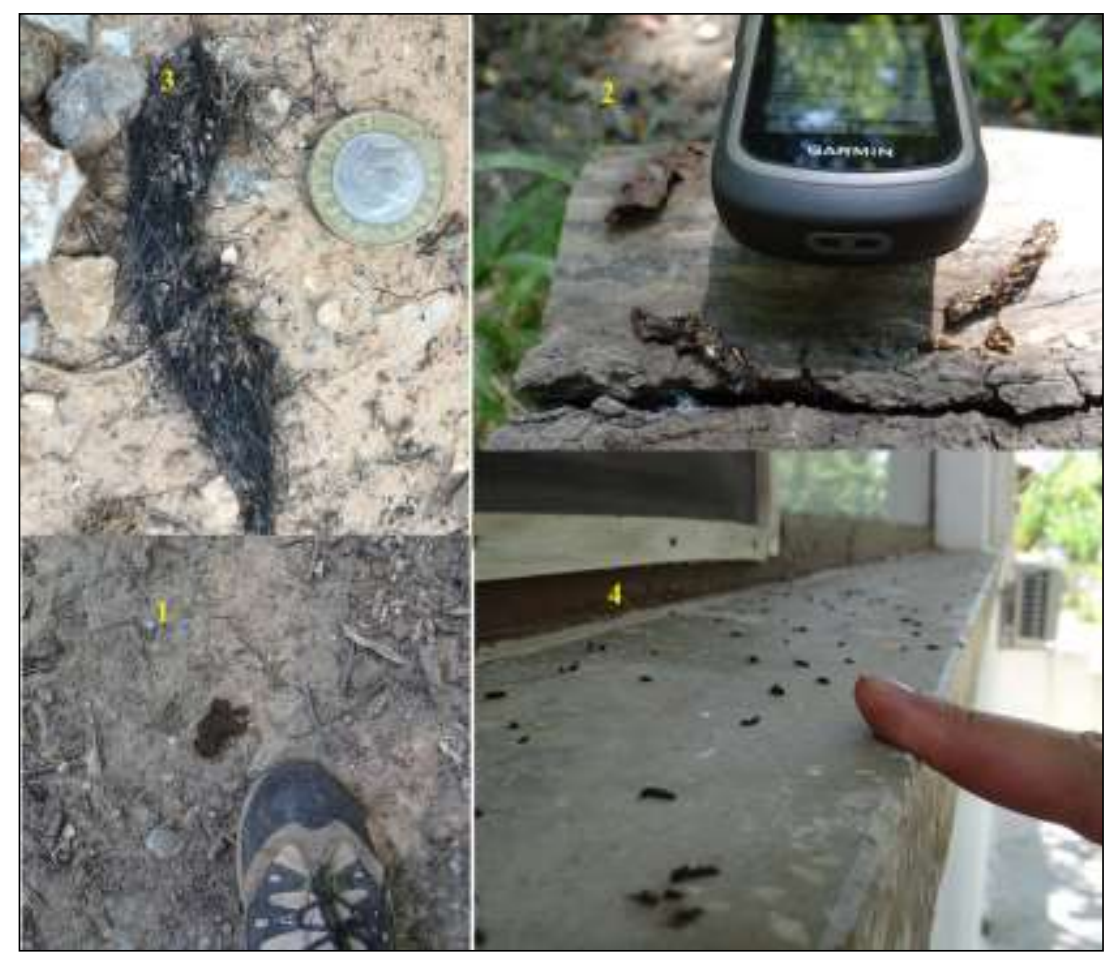

Şekil 10. Arazi çalışmaları sırasında tespit edilen memeli dışkılarından bazıları (1. Porsuk, 2. Kaya sansarı, 3.Kurt, 4. Cüce yarasa)

\section{$\underline{\text { Ölü bireyler }}$}

Kaya sansarı (Martes foina) Bafa gölünü kıyısında uzanan kara yolunda Aydın İl sınırına geçmeden hemen önce tespit edilmiştir (Şekil 11). Tespit edilen bireyin erişkin ve erkek olduğu yapılan incelemelerde anlaşılmıştır. Seydikemer İlçesi Bayır Mahallesinde bir karakulağın (Caracal caracal) yol kenarında araç çarpması sonucu öldüğü tespit edilmiştir (Şekil 12).

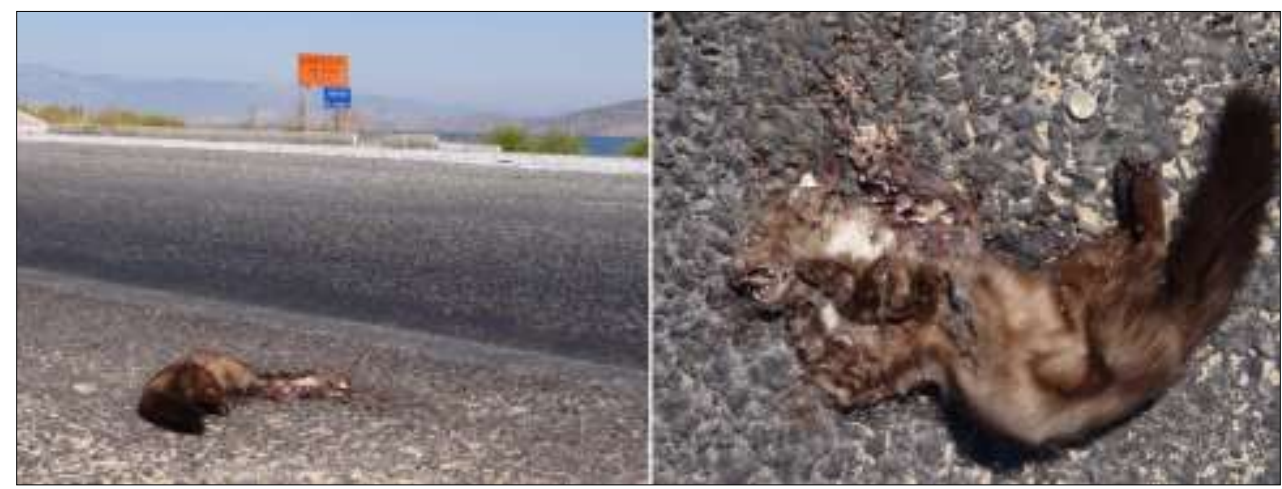

Şekil 11. Araç çarpması sonucu ölmüş Kaya sansarı (Martes foina)

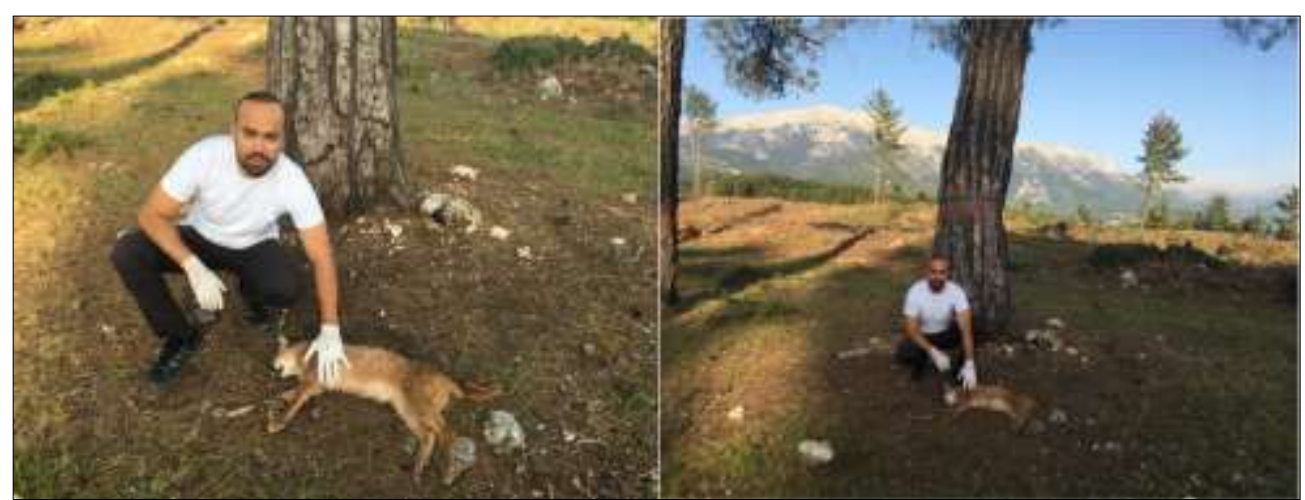

Şekil 12. 15 Haziran 2018 tarihinde Seydikemer Bayır Mahallesinde incelenen karakulak (Caracal caracal) 


\section{Foto-kapan}

Bu çalı̧̧ma kapsamında foto-kapan yöntemi kullanılarak özellikle büyük memeli türler hakkında bulgular elde edilmiştir. Elde edilen foto-kapan kayıtlarına göre tespit edilen türlerden bazıları aşağıda paylaşılmaktadır (Şekil 13).
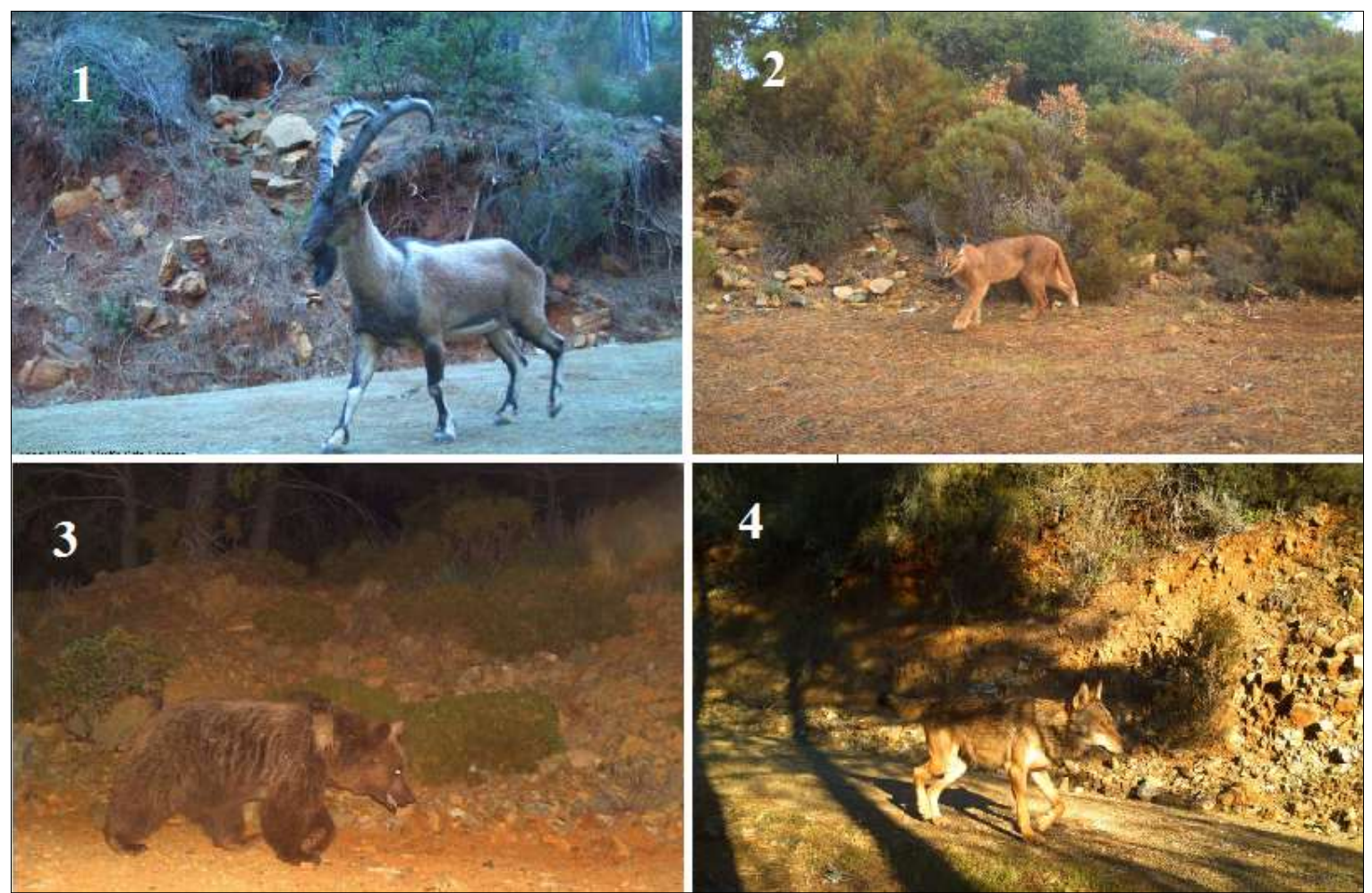

Şekil 13: Elde edilen bazı foto-kapan kayıtları. 1. Yaban keçisi, 2. Karakulak, 3. Bozayı, 4. Kurt

\section{Epidarmal yapılar ve döküntüler}

Oklu kirpiye (Hystrix indica) ait ok kalıntıları bulunmuştur (Şekil 14).

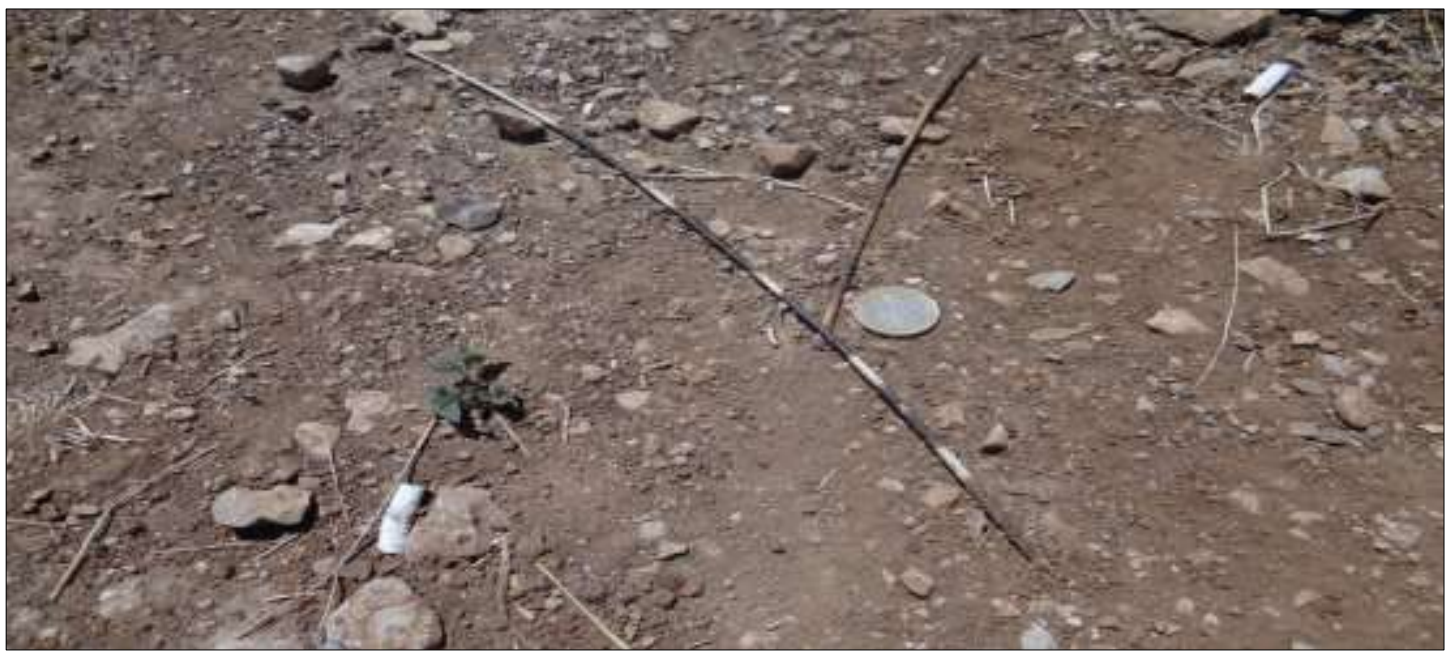

Şekil 14. Oklu kirpi (Hystrix indica) türüne ait döküntüler

\section{Yuva ile tespit}

Şekil 15'de yaban domuzuna (Sus scrofa) ait bir yatak (dinlenme noktası) verilmektedir. 


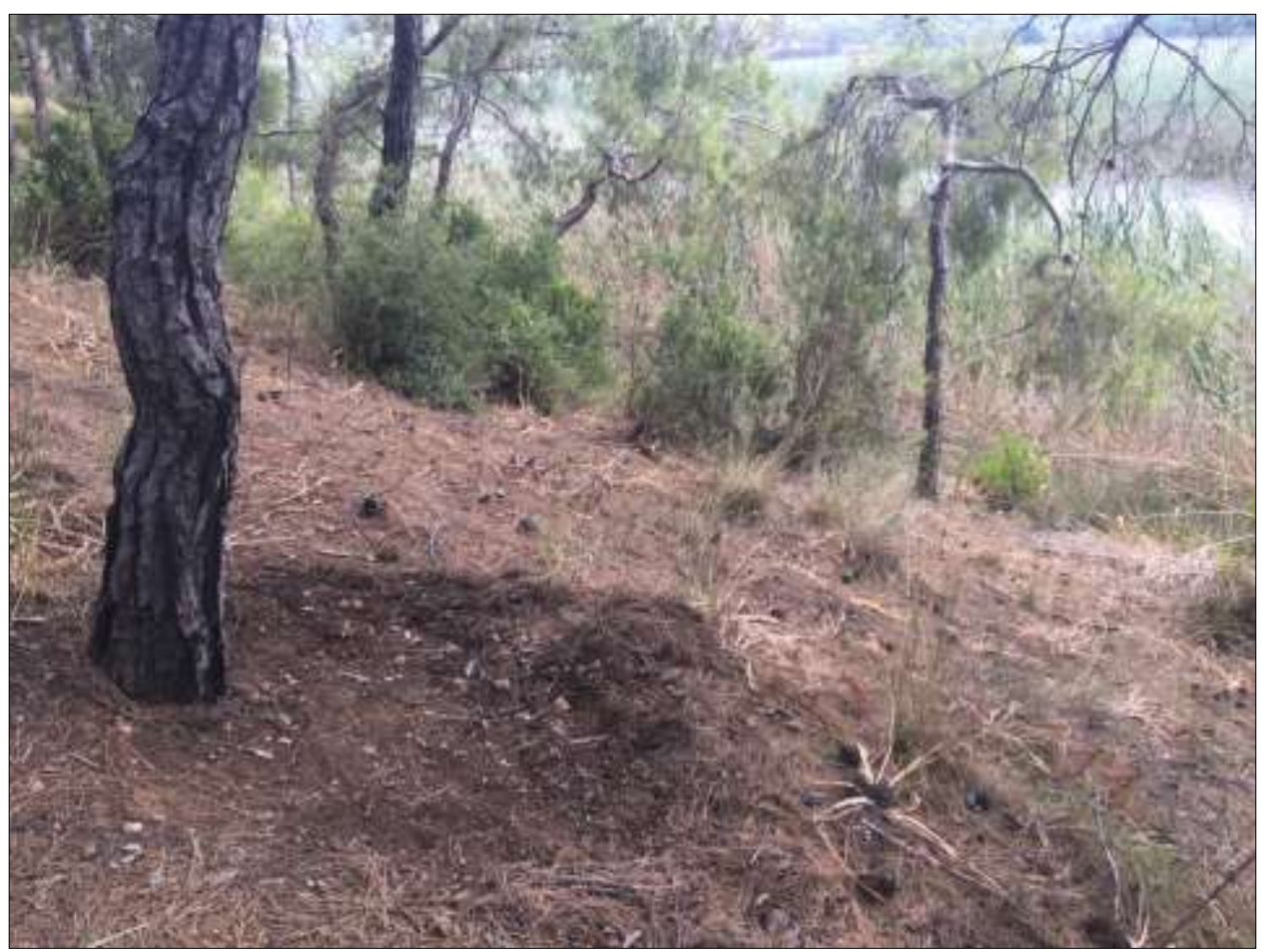

Şekil 15. Yaban domuzuna (Sus scrofa) ait bir dinlenme noktası

\section{Ultrasonik yarasa dedektörü}

"D500x Bat Detector Pettersson Elektronik" marka dedektör farklı noktalarda çalıştırılarak elde edilen ses kayıtları üzerinden yarasa tür teşhisleri yapılmıştır. Şekil 16' da Pipistrellus pipistrellus (Cüce yarasa) türüne ait sonogram örneği verilmiştir.

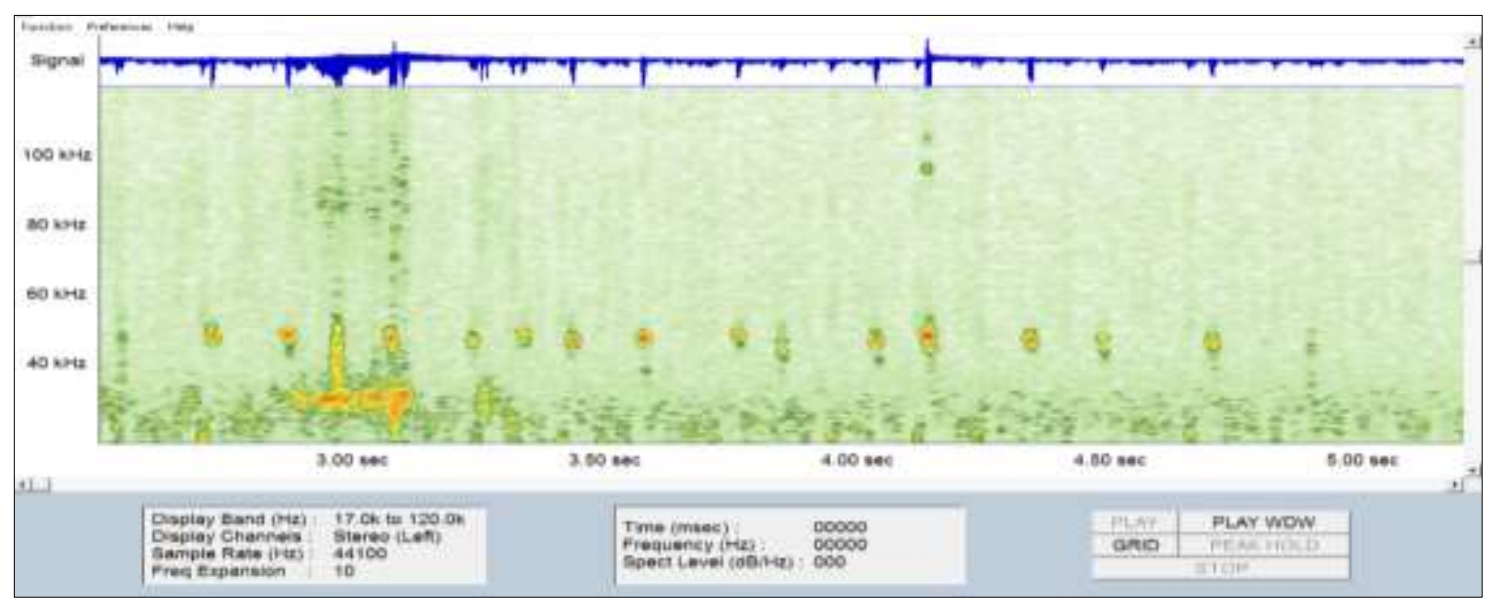

Şekil 16. Pipistrellus pipistrellus türüne ait ses sonogramı (Kaynak kişi: Tarkan Yorulmaz)

\section{Küçük memeli yakalama tuzağl}

Yakalama tuzakları ile farklı noktalarda memeli örneklemeleri yapılmıştır. Milas Korucuk mahallesinde tespit edilmiş bir Kır sivri faresi Şekil 17'de görülmektedir. 


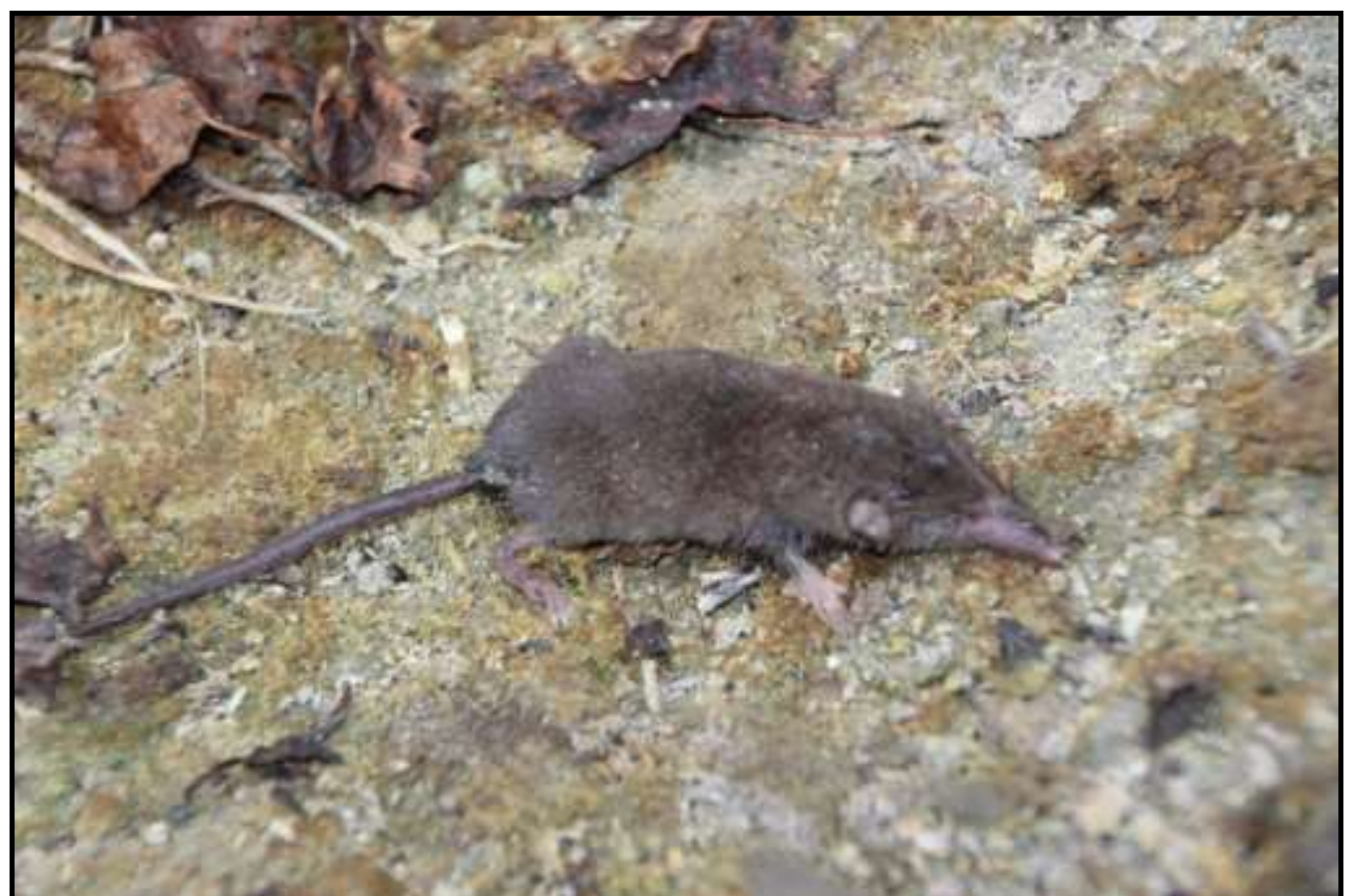

Şekil 17. Yakalama tuzağı ile yakalanıp teşhis edilen Kır sivri faresi (Crocidura leucodon) (Foto: Tarkan Yorulmaz)

Yapılan arazi ve literatür çalışmaları sonucunda Muğla İline ait güncel memeli tür listesi Tablo 1'de verilmektedir.

\section{Memelilere İliskin Tehditler}

Özellikle Muğla'da yaz aylarında trafik yoğunluğunun artmasına bağlı olarak şehirlerarası yollarda (100 km hat boyunca) yılda 5-6 porsuk bireyinin telef olduğu tutulan kayitlardan anlaşılmaktadır. $\mathrm{Bu}$ da Muğla populasyonunun nerdeyse \%16'sının sadece yollarda telef olduğu anlamına gelmektedir. Kara yollarında kaya sansarı ve karakulak ölümlerinin de fazla olduğu tespit edilmiştir. Bu oranlara kaçak avcılık, zehirleme ve habitat tahribi de eklendiğinde tehlikeli bir durum ortaya çıkmaktadır (Tablo 2).

\section{Sonuç ve Öneriler}

Bu proje kapsamında yapılan literatür ve arazi çalışmaları ile Muğla İlinde yaşayan 37 memeli türü tespit edilmiş̧ir. Tespit edilen türlerden 5 tanesi IUCN'e göre NT, 2 tanesi VU, 1 tanesi DD, 29 tanesi ise LC kategorisindedir. Bu türlerden 1 tanesi Muğla için ilk kayıttır. Alaca sansar (Vormela peregusna) ile ilgili güncel tüm kayıtların verildiği Yürümez ve Ulutürk’ün 2019 yılında yaptığı çalışmaya göre tür ile ilgili Ülkemizde 24 farklı loktaliteden kayıt bulunmaktadır. Bu lokaliteler; İstanbul, Çatalca, Istıranca Dağları, Meriç Nehri, Tekirdağ, İzmir, Eskişehir, Tuz Gölü, Vezirköprü, Samsun, Kadirli, Osmaniye, Cizre, Siirt, Kahramanmaraş, Van Gölü, Erzurum, Göle-Kars, Adana, Diyarbakır, Yeşilhisar-Kayseri, Gönen, Ceylanpınar, Batman şeklinde verilmiştir. Bu çalışma ile türün yayılışına yeni bir lokalite kaydı eklenmiştir.

Muğla İli genelinde özellikle büyük memeli türleri üzerindeki tehditlerin ortadan kaldırılmas1 için Tarım ve Orman Bakanlığı, yerel yönetimler ve Üniversite işbirliğinde planlamalar yapılmalıdır. Yaban hayvanlarının karayollarında telef olmalarının önüne geçmek amaciyla uygun habitatlarda ekosistem köprülerinin planlanmalıdır. Buna göre Muğla İlinde özellikle Köyceğiz, Döğüşbelen Mevkiinde bir ekosistem köprüsüne ihtiyaç vardır. 
Tablo 1. Muğla İli memeli tür listesi ve populasyon durumları

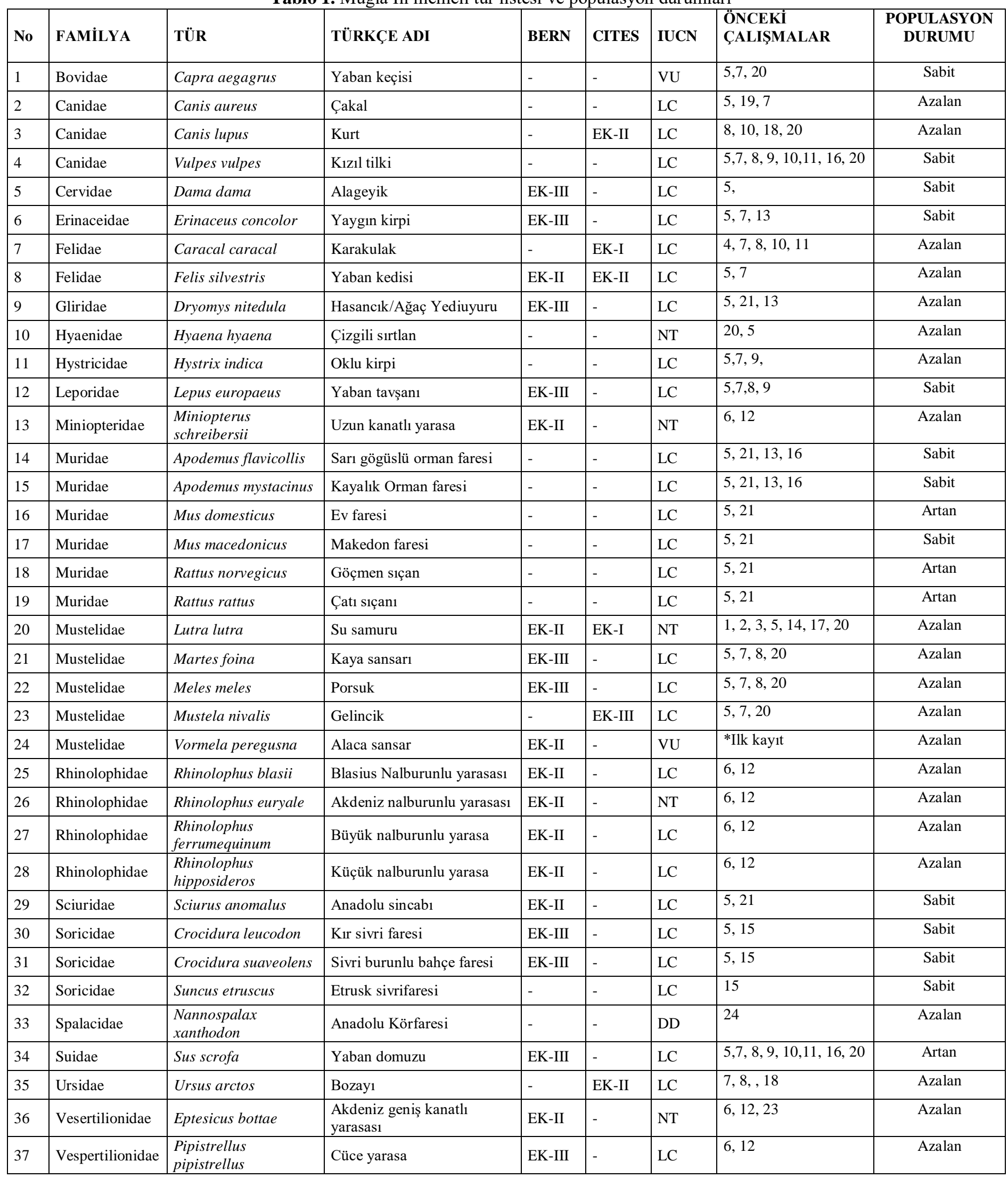


Tablo 2. Muğla İlinde memeli türler üzerindeki tehditler

\begin{tabular}{|l|l|}
\hline \multicolumn{1}{|c|}{ Türler } & \multicolumn{1}{c|}{ Tehditler } \\
\hline Çakal (Canis aureus) & Kaçak av + zehirli et \\
\hline Kurt (Canis lupus) & Kaçak av + zehirli et \\
\hline Karakulak (Caracal caracal) & Kaçak av + zehirli et \\
\hline Yaban Keçisi (Capra aegagrus) & Kaçak av \\
\hline Oklu kirpi (Hystrix indica) & Tarım ilacı+ kaçak av + habitat tahribatı \\
\hline Alaca sansar (Vormela peregusna) & Tarım ilacı+ kaçak av + habitat tahribatı \\
\hline Yaban kedisi (Felis silvestris) & Evcil kediler ile melezleşme + habitat tahribatı \\
\hline Su samuru (Lutra lutra) & Sulak alan kirliliği + kaçak av \\
\hline Bozayı (Ursus arctos) & Kaçak av + bal üreticileri ile çatışma \\
\hline
\end{tabular}

\section{Teşekkür}

Bu çalışma, Tarım ve Orman Bakanlığı, Doğa Koruma ve Milli Parklar Genel Müdürlüğünün Ulusal Biyolojik Çeşitlilik Envanter ve İzleme Projesi kapsamında Turunç Peyzaj Şirketi tarafından yürütülmüştür. Çalışma süresince desteğini esirgemeyen Dr. Tarkan YORULMAZ’a teşekkür ederim.

\section{Yazarların Katkısı}

Çalışmada tüm katkı yazara aittir.

\section{Çıkar Çatışması Beyanı}

Yazarlar arasında herhangi bir çıkar çatışması bulunmamaktadır.

\section{Araştırma ve Yayın Etiği Beyanı}

Yapılan çalışmada araştırma ve yayın etiğine uyulmuştur.

\section{Kaynaklar}

[1] Albayrak İ. 2000. Türkiye'deki Su samuru (Lutra lutra L. 1758)'nun yayıllışna katkılar. Tabiat ve İnsan, 34 (1): 3-7.

[2] Barlas M., Yorulmaz B. 2000. Su samuru (Lutra lutra)'nun Muğla ve çevresinde yayılışı. Tabiat ve İnsan, 34 (1): 18-23.

[3] Çağlar M. 1957. Fethiye civarının bazı memeli hayvanları hakkında. Biologi, Türk Biyoloji Derneğinin Yayın Organı, İstanbul, 7 (3): 72-76.

[4] Çağlar M. 1963. Felis caracal schmitsi (Matschie, 1912) in Anatolien. - İstanbul Univ. Fen Fakült. Mecmuas1, 23: 51-54.

[5] Demirsoy A. 1997. Türkiye Omurgalıları, Memeliler. Meteksan Yayınevi, Ankara, 1-292.

[6] Doğa Koruma ve Korunan Alanlar (DKMP). 2012. Yarasalar ve Mağara Ekosistemleri (Erișim tarihi: 07.02.2017).

[7] İlemin Y. 2010. Datça-Bozburun Yarımadası Orta ve Büyük Memeli Türlerinin Vejetasyon Tiplerine Bağlı Dağılımının Belirlenmesi. Yüksek Lisans Tezi, Hacettepe Üniversitesi, Fen Bilimleri Enstitüsü, Ankara.

[8] İlemin Y. 2014. A camera trapping survey reveals a melanistic grey wolf (Canis lupus) in an unusual habitat in Turkey (Mammalia: Carnivora). Zoology in the Middle East, 60 (1): 1-5.

[9] İlemin Y., Gürkan B. 2010. Status and activity patterns of the Caracal, Caracal caracal (Schreber, 1776), in Datca and Bozburun Peninsulas, Southwestern Turkey. Zoology in the Middle East, 50 (1): 3-10. 
[10] İlemin Y., Kesdek M., Koç H. 2015. Akdeniz Ekosistemleri Büyük Memeli Türleri ve Karnivor Türlerin Bu Ekosistemlerdeki Önemi: Fethiye Babadağ Örneği. Ekoloji 2015 Sempozyumu, 0609 Mayıs 2015, Sinop, Türkiye, 33.

[11] İlemin Y., Koç H. 2016. Karakulak Caracal caracal (Schreber, 1776) türünün Diyeti Üzerine Türkiye'den İlkin Bulgular. Sözlü Bildiri, 23. Ulusal Biyoloji Kongresi, 5-9 Eylül, Gaziantep, Türkiye.

[12] Karataş A., Toprak F., Karakaya H. 2002. Türkiye Yarasaları (Mammalia: Chiroptera). XVI. Ulusal Biyoloji Kongresi, 4-7 Eylül 2002, İnönü Üniversitesi Malatya.

[13] Kaynaş B.Y. 2008. Pinus brutia orman ekosistemlerinde küçük Memeli komünitesi üzerine yangının uzun dönem Etkisi ve yangınsonrası komünite yapısının Değişimi üzerine çalışmalar. Doktora Tezi, Hacettepe Üniversitesi, Fen Bilimleri Enstitüsü, Ankara.

[14] Kesim A., Başkale E., Eryiğit A., Turan Ü., Urhan R., Menengiç M., Kaska Y. 2008. Gökova Özel Çevre Koruma Bölgesindeki Su Samuru Habitatları. Su Samurunun Türkiye'deki Durumu III. Sempozyum (Uluslararası katılıml1), 23-24 Ekim, Kırıkkale, 87-98.

[15] Kryštufek B., Vohralik V. 2001. Mammals of Turkey and Cyprus. Introduction Checklist Insectivora. Science and Research Centre of the Republic of Slovenia, Koper.

[16] Kurtonur C., Özkan B., Albayrak Ş., Kıvanç E., Kefelioğlu H. 1996. Memeliler "Türkiye Omurgalilar Tür Listesi”. DPT-TBAG Nurol Matb., Ankara, 1-183.

[17] Thol-Schmitz H. 2004. Status of the Eurasian Otter, Lutra lutra, in Turkey, and experiences with establishing a National Otter Data Base. Zoology in the Middle East, 33: 109-118.

[18] Şekercioğlu Ç.H., Anderson S., Akçay E., Bilgin R., Can Ö.E., Semiz G., Sağlam İ.K. 2011. Turkey's globally important biodiversity in crisis. Biological Conservation, 144 (12): 2752-2769.

[19] Turan N. 1984. Türkiye'nin Av Ve Yaban Hayvanları, Memeliler. Ongun Kardeşler Matbaacılık Sanayii, Ankara, 1-177.

[20] Ürker O., İlemin Y., Bulut Ş., Ada E. 2015. Anadolu Sığla Ormanları (Liquidambar orientalis)'nın Biyo-Ekolojisi ve Bu Ormanlardaki Yaban Hayatı Özellikleri Hakkında Güncel Bir Değerlendirme. Sözlü Bildiri, XII. Ulusal Ekoloji ve Çevre Kongresi 14-17 Eylül 2015, Muğla, Türkiye.

[21] Yiğit N., Çolak E., Sözen M., Karataş A. 2006. Rodents of Türkiye (Türkiye Kemiricileri). Meteksan, Ankara, 1-114.

[22] Ulutürk S., Yürümez G. 2019. Vormela peregusna'nın Türkiye'deki Dağılışı ve Ekolojileri Üzerine Katkılar. Kommagene Biyoloji Dergisi, 3 (1): 53-55.

[23] Aulagnier S., Karataş, A., Tsytsulina K. 2008. Eptesicus bottae. The IUCN Red List of Threatened Species 2008: e.T7915A12869203.

[24] Arslan A., Kryštufek B., Matur F., Zima, J. 2016. Review of chromosome races in blind mole rats (Spalax and Nannospalax). Folia Zoologica, 65 (4): 249-301. 